\title{
Ex-post evaluation of public funding programs on innovation in chilean firms
}

\author{
Evaluación ex-post de programas de financiamiento público \\ sobre la innovación en firmas chilenas
}

\author{
Cristian Mardones* \\ Universidad de Concepción, Chile \\ Received November 20, 2019; accepted June 15, 2020 \\ Available online September 2, 2020
}

\begin{abstract}
This study uses panel data to investigate the impact of programs funded by Chilean economic development agency (CORFO). The data correspond to the 1st, 2nd, and 3rd waves of the Longitudinal Survey of Firms. This study demonstrates that the impact of INNOVA program on firm's probability of generating innovation in products and/or services disappears when innovative characteristics are controled. Moreover, as these variables are observables in the selection process is possible that CORFO could be 'picking winners' that had developed these innovations independently of public funding. Furthermore, it is found that FOGAPE program changes the firms' funding sources.
\end{abstract}

JEL Code: $\mathrm{C} 23, \mathrm{O} 31, \mathrm{O} 38$

Keywords: Ex-post evaluation; Innovation; R\&D; Panel data; Picking winners

\footnotetext{
*Corresponding author.

E-mail address: crismardones@udec.cl (C. Mardones).

Peer Review under the responsibility of Universidad Nacional Autónoma de México. 


\section{Resumen}

Este estudio utiliza datos de panel para investigar el impacto de diversos programas financiados por la Corporación de Fomento Productivo (CORFO). Los datos provienen de la $1^{\mathrm{a}}$, $2^{\mathrm{a}}$ y $3^{\mathrm{a}}$ ronda de la Encuesta Longitudinal de Empresas. Este estudio demuestra que cuando se controla por las características innovativas de las empresas desaparecen los efectos del programa INNOVA sobre la probabilidad de generar innovaciones en productos y/o servicios. Además, como estas características son observables en el proceso de selección de beneficiarios, CORFO podría estar 'escogiendo ganadores' que hubiesen desarrollado estas innovaciones independientemente del financiamiento público. También, se concluye que el programa FOGAPE modifica las fuentes de financiamiento de las firmas.

Código JEL: C23, O31, $\mathrm{O} 38$

Palabras clave: Evaluación ex-post; Innovación; I+D; Datos de panel; Escogiendo ganadores

\section{Introduction}

Innovation policy has emerged as a new area of economics during the last three decades (Fagerberg, 2017). This is explained because the innovation is crucial for long-term economic growth and introduces novelty (variety) into the economy, but the innovation tends to cluster in certain sectors, which explains differences in performance between firms, regions, and countries (Fagerberg, 2006). Moreover, innovation is a source of productivity for firms, but due to its public good characteristics, there is a suboptimal level of innovative efforts (d'Artis \& Siliverstovs, 2016, Crespi, 2012, among others). For the above reasons, the role of the state in innovation processes could be seen as correcting market and system failures that limit the development of knowledge, technology, and innovation (Borras \& Edler, 2020; Edler \& Fagerberg, 2017; Martin \& Scott, 2000).

In the case of Chile, in 1939 the Production Development Corporation (CORFO) was created, which in its beginnings helped in the industrialization of the country but changed its development strategy in the following decades due to the new development model based in the free market and openness to international trade. At the beginning of the 90's CORFO began to develop a set of programs of subsidies and credits to support the growth of the firms. At present, CORFO seeks to boost research and technological development with economic impact, encourage collaboration between firms, increase market competitiveness, encourage private investment and facilitate funding; then it has designed different programs with specific characteristics according to the desired objectives. 
According to the data from the Longitudinal Survey of Firms, most programs used by firms and funded by CORFO are: a) The Guarantee Fund for Small Business Owners (FOGAPE) that allows access to funding for productive purposes, either working capital or investment; b) The Supplier Development Program (PDP) that seeks to support supplier firms or firms that have the potential to become direct suppliers of large firms, subsidizing part of the cost of diagnostic activities, design and implementation of a work plan to improve their skills and competences; c) The INNOVA program that includes different funding lines focused at promoting innovation, knowledge transfer, and technological capabilities; d) The Quality Development Program (FOCAL), which seeks to improve the competitiveness and productivity of firms by encouraging the implementation and certification of management system standards, protocols or products in their firms that allow access to more sophisticated or export markets; e) Technical Assistance Fund (FAT), which is a non-reimbursable contribution that covers part of the cost of a specialized consultancy to improve the firm management.

Despite the proliferation of many of these public funding programs, there is little evidence to support their effectiveness on innovative outputs in Chilean firms. For this reason, the present study seeks to complement previous studies1 and evaluate the impact of CORFO on innovation in products and/or services, identifying if these programs have displaced private investment.

For this study, the information obtained from the three versions of the Longitudinal Survey of Firms (ELE) conducted in Chile covering the years 2007, 2009, and 2013 is used. The impact of the programs is estimated using econometric techniques for panel data using the subgroup of firms present in the three versions of the survey.

\section{Literature review}

Importance of public funding for innovation

Innovation positively depends on $\mathrm{R} \& \mathrm{D}$ expenditure, the absorption capacity of firms, and a strong institutionality provided by the State (Bianchini et al., 2019). Therefore, it is not surprising that many studies show that public funding fosters R\&D, innovation and/or productivity (Kim, 2020; Aiello et al., 2019; Minford \& Meenagh 2019; Liu et al. 2016; Yu et al., 2016; Bronzini \& Piselli, 2016; Becker, 2015; Guan \& Yam, 2015; King \& Wooley, 2014). Public funding can also contribute to improving innovation networks and

\footnotetext{
${ }^{1}$ This estudies have been concentrated mainly on estimating the impact on sales, profits, labor productivity, total factor productivity and workers hiring.
} 
ecosystems (Edler \& Fagerberg, 2017; Oh et al., 2016). However, there are studies that argue that public funds can partially or totally replace private investment (Petrin, 2018; Marino et al., 2016). Consequently, it is important to increase the evidence on the impact of public funding on weak innovation ecosystems such as latin americans (Crespi et al., 2016) since the results obtained in developed countries cannot be easily extrapolated to developing countries (Castellacci \& Lie, 2015).

\section{Ex-post evaluation of public funding programs for innovation}

The use of ex-post evaluation techniques to evaluate innovation policies is quite widespread at the international level (Stojčić et al., 2020; Wellalage \& Fernandez, 2019; Doran \& Ryan, 2019; Bai et al., 2018). Also, there are evaluations of this type in Latin American countries. For example, Crespi et al. (2016) use two waves of innovation surveys from 1998 to 2004, demonstrating with GMM techniques that tax credit policy has a significant effect in promoting R\&D in Argentina. Crespi et al. (2011) evaluated the impacts of programs associated with financial incentives for R\&D in Colombia using a longitudinal database between 1995 and 2007, their results show that the support received by firms had a significant impact on their results, that these effects were maintained in time and even that in some cases the effect increased along the years. Crespi \& Zuñiga (2012) showed that firms that received public funding for innovation invested significantly more than those firms that did not receive the fund, in the case of Chile and Colombia they invested about $80 \%$ more. Hall \& Maffioli (2008) evaluated public funding for technological development in Argentina, Chile, Brazil, and Panama, determining that the technological development funds positively affected the R\&D intensity, they did not displace private investment, and on the contrary, in many cases, R\&D investment increased significantly. López (2009) carried out a review of several studies developed in Latin America, concluding that in Brazil and Argentina the beneficiary firms increased their R\&D expenditure more than the subsidy amount received; in the case of Chile and Panama, funding programs positively affected the ability of firms to interact with external sources of knowledge and funding, and also improved the scope of their innovations. They also found positive effects on employment in Chile and Brazil, on exports in Chile, and on productivity in Colombia and Panama. 


\section{Ex-post evaluation of public funding programs in Chile}

The government agency responsible for evaluating publicly funded programs in Chile is the National Budget Office (DIPRES), which reports to the Ministry of Finance. For this reason, DIPRES has carried out the ex-post evaluation of some programs managed by CORFO. DIPRES (1998) tried to evaluate the FAT program but the lack of adequate sources of information prevented it, so this study merely suggested a more complete characterization of the potential beneficiaries to evaluate the program years later. RISMIP (2011) carried out an ex-post evaluation of a set of CORFO programs from 2002 to 2008, this study was contracted by DIPRES and had access to beneficiaries' data provided by CORFO, as well as to restricted access information provided by the Chile's Tax Administration (SII). Thus, it was possible to build panel data with beneficiary and non-beneficiary firms to use matching techniques and differences in differences. The results indicated that the FAT program had no impact on sales, profits, labor productivity, and number of workers, while that the FOCAL program had a positive impact on sales, profits, and margins, but it did not affect labor productivity. The results also proved that PROFO program did not have a positive impact on the primary sector and the services sector, but positively affected margins in the manufacturing sector, and that PDP program had a positive impact on supplier firms through an increase in sales.

Some studies have used the Chilean Innovation Survey to analyze the aggregate impact of the various public funding instruments for innovation. For example, Mardones \& Zapata (2019) analyzed the effect of public funding on the probability of performing various innovative activities in Chilean firms using binary choice models with pseudo-panel data (repeated cross-sectional data from Chilean Innovation Surveys) during the period of 2007-2014, concluding that public funding increases innovative inputs, but the results are not robust on innovative outputs. Benavente (2005) using cross-sectional data estimated several econometric models for each of the three versions of the Chilean Innovation Survey (1995, 1998, and 2001), concluding that public funding for R\&D affected productivity through impact on research expenditure and, through this, on product innovations.

However, other studies have analyzed the impact of specific public instrument with panel data usign restricted access information. For example, Arráíz et al. (2012) evaluated the impact of the PDP program in the period 1998-2008, for which they used differences in differences and matching techniques with panel data that included information from SII and CORFO, finding that this program increased sale, employment, and sustainability of small- and medium-sized suppliers, and it was also observed that large firms increased their 
probability of becoming exporters. Benavente \& Crespi (2003) analyzed the effects of participating in a PROFO program in the early 1990s, for which they studied a group of firms that had completed three years of participation in the program, and then compared it with another group of similar firms. The results showed improvements in administration, planning and marketing, also allowed greater access to other programs such as FONTEC ${ }^{1}$ and FAT, and also found that participation was associated with increases in total factor productivity, although it was not observed impacts on the innovation of processes or products. Tan (2009) used the method of differences in differences combined with propensity score matching for the period 1992-2006, determining that participation in the FAT and PROFO programs had a positive and statistically significant effect on sales, production, labor productivity, wages, and exports, but FONTEC showed smaller impacts on these variables. Opposite results on the impact of participating in the FONTEC program were obtained by Benavente et al. (2007) who, using the differences in differences method, found that participating in this program led to a shift in own resources invested in $\mathrm{R} \& \mathrm{D}$, increased interactions with external sources of knowledge and funding, improved process innovation, but did not affect creation of new products. In addition, they found positive effects on employment, sales, and exports, but did not show a significant impact on productivity. Álvarez et al. (2012) determined that FONTEC had a positive impact on employment, wages, labor productivity and total factor productivity, but the effect on labor productivity and wages was concentrated in the first three years of program use. They also analyzed FONDEF concluding that this program generated negative impacts on employment and positive effects on labor productivity. Finally, Crespi et al. (2020) estimate the effects of FONTEC and FONDEF using a panel data that merges several waves of National Manufacturing Surveys and information from CORFO, the results show that both programs increases the productivity, but only FONDEF generates positive spillovers on firms' productivity.

\section{Available data}

The Longitudinal Survey of Firms (ELE) includes three waves conducted in the years 2007, 2009, and 2013, all drawn up by the Ministry of Economy and the National Statistics Institute. In general terms, the survey consists of five modules: accounting and finance, marketing and entrepreneurial environment, general management, human resources, and information and communication technologies.

In 2007 there were records of 10,213 firms surveyed, of which 152 received funding from a CORFO program, in 2009 there were records of 7,062 firms, of whom 218 received funding 
from a CORFO program, and in the year 2013 there are records of 7,267 firms of whom 292 received funding from some CORFO program. However, it is necessary to remark that the same firms have not been surveyed in all the ELE waves, some of them only in the first wave, others in the first and second (2,667 firms), others in the second and third (559 firms), and the same subgroup is in the first, second, and third (559 firms).

Table 1 presents the descriptive statistics of the variables used in this study. Firms that declare innovation for the introduction of new products and/or services correspond to $16.3 \%$ in $2007,11.5 \%$ in $2009^{2}$ and $15.6 \%$ in 2013 . Most of the firms included in the survey are medium and large, and also belong to the industrial sector, construction and transport - communications. The average real sales of firms are approximately 52 billion of Chilean pesos in 2007, 49 billion of Chilean pesos in 2009 and 62 billion of of Chilean pesos in 2013. On the other hand, $92.3 \%$ of the firms are nationally owned, $6.7 \%$ foreign owned, and the rest are publicly owned firms. Most of the surveyed firms are limited liability firms (36.9\%) and closed corporations (34.0\%). In addition, $2.9 \%$ of the firms that are present in the three waves of ELE have obtained the funding from some program of CORFO in some waves. The PDP program has financed firms included in the three waves of the ELE, the INNOVA program has funded firms included only in the second and third waves of the ELE, the FOGAPE and FAT programs have funded firms included only in the first and second waves of the ELE, while other CORFO programs have funded firms included in the three follow-up waves. Finally, it should be mentioned that questions associated with innovative inputs, such as recruiting $R \& D$ personnel or having an $R \& D$ department, are only available for the second and third waves of the ELE survey.

Table 1

Descriptive Statistics

\begin{tabular}{|c|c|c|c|c|c|c|c|c|c|c|c|c|c|c|c|}
\hline \multirow[b]{2}{*}{ Variable } & \multicolumn{5}{|c|}{ Year 2007} & \multicolumn{5}{|c|}{ Year 2009} & \multicolumn{5}{|c|}{ Year 2013} \\
\hline & Obs. & Mean & St. Dev. & Min. & Max. & Obs. & Mean & St. Dev. & Min. & Max. & Obs. & Mean & St. Des. & Min. & Max. \\
\hline $\begin{array}{l}\text { Innovation in } \\
\text { new products } \\
\text { and services }\end{array}$ & 559 & 0.1628 & 0.3695 & 0 & 1 & 559 & 0.1145 & 0.3187 & 0 & 1 & 559 & 0.1556 & 0.3628 & 0 & 1 \\
\hline Small firm 1 & 559 & 0.0555 & 0.2291 & 0 & 1 & 559 & 0.0626 & 0.2425 & 0 & 1 & 559 & 0.0537 & 0.2256 & 0 & 1 \\
\hline Small firm 2 & 559 & 0.1699 & 0.3759 & 0 & 1 & 559 & 0.1878 & 0.3909 & 0 & 1 & 559 & 0.1753 & 0.3806 & 0 & 1 \\
\hline Large firm & 559 & 0.2397 & 0.4273 & 0 & 1 & 559 & 0.2182 & 0.4134 & 0 & 1 & 559 & 0.2057 & 0.4046 & 0 & 1 \\
\hline Medium firm & 559 & 0.4812 & 0.5001 & 0 & 1 & 559 & 0.4848 & 0.5002 & 0 & 1 & 559 & 0.5098 & 0.5004 & 0 & 1 \\
\hline $\begin{array}{l}\text { Agricultural } \\
\text { sector }\end{array}$ & 559 & 0.0429 & 0.2029 & 0 & 1 & 559 & 0.0519 & 0.222 & 0 & 1 & 559 & 0.0465 & 0.2108 & 0 & 1 \\
\hline Mining sector & 559 & 0.0519 & 0.2220 & 0 & 1 & 559 & 0.0465 & 0.2108 & 0 & 1 & 559 & 0.0447 & 0.2069 & 0 & 1 \\
\hline
\end{tabular}

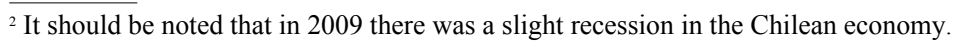




\section{Mardones / Contaduría y Administración 66(3), 2021, 1-19}

http://dx.doi.org/10.22201/fca.24488410e.2021.2683

\begin{tabular}{|c|c|c|c|c|c|c|c|c|c|c|c|c|c|c|c|}
\hline $\begin{array}{l}\text { Manufactu- } \\
\text { ring industry } \\
\text { sector }\end{array}$ & 559 & 0.1306 & 0.3373 & 0 & 1 & 559 & 0.1288 & 0.3353 & 0 & 1 & 559 & 0.1610 & 0.3679 & 0 & 1 \\
\hline $\begin{array}{l}\text { Electrici- } \\
\text { ty-gas-water } \\
\text { sector }\end{array}$ & 559 & 0.0268 & 0.1617 & 0 & 1 & 559 & 0.0304 & 0.1719 & 0 & 1 & 559 & 0.0322 & 0.1767 & 0 & 1 \\
\hline $\begin{array}{l}\text { Construction } \\
\text { sector }\end{array}$ & 559 & 0.1091 & 0.3121 & 0 & 1 & 559 & 0.0984 & 0.2981 & 0 & 1 & 559 & 0.1073 & 0.3098 & 0 & 1 \\
\hline $\begin{array}{l}\text { Commerce } \\
\text { sector }\end{array}$ & 559 & 0.2540 & 0.4357 & 0 & 1 & 559 & 0.2540 & 0.4357 & 0 & 1 & 559 & 0.2326 & 0.4228 & 0 & 1 \\
\hline $\begin{array}{l}\text { Hotels and } \\
\text { restaurants } \\
\text { sector }\end{array}$ & 559 & 0.1002 & 0.3005 & 0 & 1 & 559 & 0.0966 & 0.2957 & 0 & 1 & 559 & 0.1020 & 0.3029 & 0 & 1 \\
\hline $\begin{array}{l}\text { Transport and } \\
\text { communica- } \\
\text { tions sector }\end{array}$ & 559 & 0.1342 & 0.3411 & 0 & 1 & 559 & 0.1306 & 0.3373 & 0 & 1 & 559 & 0.1324 & 0.3392 & 0 & 1 \\
\hline $\begin{array}{l}\text { Financial } \\
\text { sector }\end{array}$ & 559 & 0.0501 & 0.2183 & 0 & 1 & 559 & 0.0483 & 0.2146 & 0 & 1 & 559 & 0.0483 & 0.2146 & 0 & 1 \\
\hline $\begin{array}{l}\text { Real estate } \\
\text { and business } \\
\text { services }\end{array}$ & 559 & 0.0358 & 0.1859 & 0 & 1 & 559 & 0.0483 & 0.2146 & 0 & 1 & 559 & 0.0233 & 0.1508 & 0 & 1 \\
\hline Service sector & 559 & 0.0644 & 0.2457 & 0 & 1 & 559 & 0.0662 & 0.2488 & 0 & 1 & 559 & 0.0698 & 0.255 & 0 & 1 \\
\hline $\begin{array}{l}\text { Real sales in } \\
\text { millions of } \\
\text { Chilean \$ }\end{array}$ & 559 & 52726 & 270491 & 1.2488 & $5 E+06$ & 540 & 49326 & 172659 & 0.8177 & $2 \mathrm{E}+06$ & 559 & 62538 & 209114 & 0 & $2 \mathrm{E}+06$ \\
\hline $\begin{array}{l}\text { Number of } \\
\text { employees }\end{array}$ & 548 & 297.74 & 947.19 & 0 & 14862 & 559 & 636.96 & 2595.8 & 0 & 46725 & 559 & 4223.9 & 13263 & 0 & 129886 \\
\hline $\begin{array}{l}\% \text { National } \\
\text { private } \\
\text { ownership }\end{array}$ & 559 & 92.263 & 26.063 & 0 & 100 & 559 & 92.716 & 25.109 & 0 & 100 & 559 & 93.165 & 24.569 & 0 & 100 \\
\hline $\begin{array}{l}\% \text { Foreign } \\
\text { private } \\
\text { ownership }\end{array}$ & 559 & 6.7281 & 24.507 & 0 & 100 & 559 & 6.2021 & 23.335 & 0 & 100 & 559 & 5.8265 & 22.65 & 0 & 100 \\
\hline $\begin{array}{l}\text { Natural } \\
\text { person }\end{array}$ & 559 & 0.1646 & 0.3711 & 0 & 1 & 559 & 0.1592 & 0.3662 & 0 & 1 & 559 & 0.1610 & 0.3679 & 0 & 1 \\
\hline $\begin{array}{l}\text { Limited } \\
\text { liability firm }\end{array}$ & 559 & 0.3685 & 0.4828 & 0 & 1 & 559 & 0.3810 & 0.4861 & 0 & 1 & 559 & 0.3417 & 0.4747 & 0 & 1 \\
\hline $\begin{array}{l}\text { Limited } \\
\text { individual } \\
\text { liability firm }\end{array}$ & 559 & 0.0161 & 0.126 & 0 & 1 & 559 & 0.0125 & 0.1113 & 0 & 1 & 559 & 0.0411 & 0.1988 & 0 & 1 \\
\hline $\begin{array}{l}\text { Collective } \\
\text { society }\end{array}$ & 559 & 0.0018 & 0.0423 & 0 & 1 & 559 & 0.0036 & 0.0598 & 0 & 1 & 559 & 0.0018 & 0.0423 & 0 & 1 \\
\hline $\begin{array}{l}\text { Close } \\
\text { corporation }\end{array}$ & 559 & 0.3399 & 0.4741 & 0 & 1 & 559 & 0.3399 & 0.4741 & 0 & 1 & 559 & 0.3274 & 0.4697 & 0 & 1 \\
\hline $\begin{array}{l}\text { Open } \\
\text { corporation }\end{array}$ & 559 & 0.0590 & 0.2359 & 0 & 1 & 559 & 0.0644 & 0.2457 & 0 & 1 & 559 & 0.0751 & 0.2638 & 0 & 1 \\
\hline $\begin{array}{l}\text { Make direct } \\
\text { exports }\end{array}$ & 559 & 0.1449 & 0.3523 & 0 & 1 & 559 & 0.1503 & 0.3577 & 0 & 1 & 559 & 0.1682 & 0.3743 & 0 & 1 \\
\hline PDP Program & 559 & 0.0072 & 0.0844 & 0 & 1 & 559 & 0.0054 & 0.0731 & 0 & 1 & 559 & 0.0054 & 0.0731 & 0 & 1 \\
\hline $\begin{array}{l}\text { INNOVA } \\
\text { Program }\end{array}$ & 559 & 0.0000 & 0.0000 & 0 & 0 & 559 & 0.0107 & 0.1031 & 0 & 1 & 559 & 0.0054 & 0.0731 & 0 & 1 \\
\hline $\begin{array}{l}\text { FOGAPE } \\
\text { Program }\end{array}$ & 559 & 0.0036 & 0.0598 & 0 & 1 & 559 & 0.0089 & 0.0942 & 0 & 1 & 559 & 0.0000 & 0.0000 & 0 & 0 \\
\hline FAT Program & 559 & 0.0018 & 0.0423 & 0 & 1 & 559 & 0.0018 & 0.0423 & 0 & 1 & 559 & 0.0000 & 0.0000 & 0 & 0 \\
\hline $\begin{array}{l}\text { Another } \\
\text { CORFO } \\
\text { program }\end{array}$ & 559 & 0.0089 & 0.0942 & 0 & 1 & 559 & 0.0089 & 0.0942 & 0 & 1 & 559 & 0.0089 & 0.0942 & 0 & 1 \\
\hline $\begin{array}{l}\text { Department of } \\
\text { R\&D }\end{array}$ & 0 & . & . & . & . & 559 & 0.1270 & 0.3333 & 0 & 1 & 559 & 0.0716 & 0.2580 & 0 & 1 \\
\hline $\begin{array}{l}\text { Recruitment } \\
\text { of R\&D } \\
\text { personnel }\end{array}$ & 0 & . & . & . & . & 559 & 0.1503 & 0.3577 & 0 & 1 & 559 & 0.0447 & 0.2069 & 0 & 1 \\
\hline
\end{tabular}

Source: Own elaboration. 


\section{Methodology}

One of the main difficulties in identifying the impact of a public funding program on innovation is that it is not possible to observe the result variable (in this case innovation in products and/ or services) for the same firm with treatment (public funding program) or without treatment at the same instant of time.

This would not generate an econometric identification problem if the treatment was randomly assigned to the firms, but in practice it is not common that there is a random assignment due to the self-selection of the applicants to participate in this type of programs. However, it is possible to use a difference in differences estimator to estimate the average treatment effect in the treated group (assuming that the control group is a good estimate of the change experienced by the treated group if it had not received the treatment. Specifically, this method assumes that unobservable factors remain constant over time, that is, that there are common temporal effects across the treatment and control groups, and further, that it does not systematically change the composition within each group. The differences in differences estimator can also be implemented with panel data for longer periods through the following fixed-effects specification:

$$
y_{i t}=\boldsymbol{x}^{\prime}{ }_{i t} \boldsymbol{\beta}+\mu_{i}+\lambda_{t}+\varepsilon_{i t} \quad i=1, \ldots, N ; \quad t=1, \ldots, T
$$

Where $y_{i t}$ is the dependent variable (innovation in products and/or services) of firm $i$ in period $t, \boldsymbol{x}_{i t}$ corresponds to the vector of explanatory variables (which includes a constant, characteristics of the firms and if they were awarded by the different programs of CORFO), $\beta$ is the parameter vector of interest (which includes the effect of each of CORFO's funding programs), and in addition, the random error term is composed of a specific unobservable effect for each $i\left(\mu_{i}\right)$, a specific unobservable effect for each $t\left(\lambda_{t}\right)$, and an effect that varies with $i$ y $t\left(\varepsilon_{i t}\right)$.

Among the benefits of using panel data is the control of individual heterogeneity, which reduces the risk of biased results. In addition, panel data provides more information, more variability, less colinearity between variables, more freedom degrees, and greater efficiency. One of its main attractions is that it allows identifying and measuring effects that are not easily detectable with cross-sectional data or time series. However, there may be problems with the design and collection of information as firms could deliver incomplete data or simply refuse to respond over time, which can lead to distortions in measurement of variables and selectivity problems. 
In the case that the dependent variable is binary (innovates or does not innovate in products and/or services) the structural model can be specified as:

$$
\begin{gathered}
y_{i t}^{*}=\boldsymbol{x}^{\prime}{ }_{i t} \boldsymbol{\beta}+\mu_{i}+\varepsilon_{i t} \quad i=1, \ldots, N ; \quad t=1, \ldots, T \\
y_{i t}=1 \quad \text { if } y_{i t}^{*}>0, \text { and } 0 \text { in other case }
\end{gathered}
$$

As before, $\mu_{i}$ is the unobserved individual heterogeneity. In this case $\mu_{i}$ and $\beta$ are the parameters to be estimated, but when $N \rightarrow \infty$ given a fixed $T$, the number of $\mu_{i}$ parameters is increased with $N$, so they can not be estimated consistently due to the problem of incidental parameters. In addition, the parameter $\beta$ can not be consistently estimated with a model in differences when the dependent variable is binary.

Therefore, Chamberlain (1980) suggested to maximize a conditional distribution function to obtain estimates of $\beta$. In the case of a fixed-effects logit model only the observations of the individuals that change their state should be used, which implies to use a traditional logit that includes as explanatory variables to $\boldsymbol{x}_{i t}^{\prime}-\boldsymbol{x}^{\prime}{ }_{i t-1}$, whereas the dependent variable takes the value 1 if $y_{i t}$ changes from 1 to 0 , and the value 0 if $y_{i t}$ changes from 0 to 1 . This estimator is consistent and efficient only if there are no individual effects, otherwise they are inefficient because not all data are used. In addition, this approach does not generate computational simplifications that allow to estimate a probit model of fixed effects.

However, assuming that $\mu_{i}$ is not related to $\boldsymbol{x}_{i t}$ the conditional distribution $\mu_{i}$ is not dependent on $\boldsymbol{x}_{i t}$, generating the so-called random effects binary model ${ }^{3}$. The probit specification is popular for estimating this model, whose fundamental assumption is that there is equicorrelation between successive errors belonging to the same unit. In this case $u_{i}=\mu_{i}+\varepsilon_{i t}$, it is also assumed that $\mu_{i} \sim \operatorname{IIN}\left(0, \sigma_{\mu}^{2}\right)$ and $\varepsilon_{i t} \sim \operatorname{IIN}\left(0, \sigma_{\varepsilon}^{2}\right)$ are independent of each other and independent of $\boldsymbol{x}_{i t}^{\prime}$. As $\mathrm{E}\left(u_{i t}, u_{i s}\right)=\sigma_{\mu}^{2}$ for $t \neq s$, the joint probability $\left(y_{1 t}, \ldots, y_{N t}\right)$ can not be written as the multiplication of the marginal probabilities of $y_{i t}$, which complicates the estimation by maximum likelihood because it involves integrals with $T$ dimensions. Fortunately, by conditioning for individual effects, the problem is reduced to a single integral involving the multiplication of a standard normal density function and $T$ differences of two normal cumulative functions that are estimated with a Gaussian quadrature procedure.

\footnotetext{
${ }^{3}$ If both variables are correlated the so-called fixed effects model emerges, under this assumption a problem of incidental parameters appears that leads to an inconsistency in the maximum likelihood estimator.
} 


\section{Results}

Different specifications of empirical models controlled by different groups of variables were generated to evaluate the impact of different CORFO's funding programs on the probability of innovations in products and/or services in Chilean firms. Specification 1 only includes funding programs without control variables. Specification 2 also includes control variables such as sales, number of employees, percentage of national private ownership, percentage of foreign private ownership, type of legal form of the firm (natural person, limited liability firm, individual liability firm, collective society, closed corporation, and open corporation) and if the firm exports. In specification 3 also includes as control variable the size of the firm (small 1, small 2, medium, and large). In addition, the economic sector (agricultural, mining, manufacturing, electricity - gas - water, construction, commerce, hotels - restaurants, transportation - communications, financial, real estate - business services, and services).

Table 2 shows the probit regressions with random effects that include the data from the three waves of the ELE survey. This table shows that the probability of performing innovation in products and/or services is affected positively and statistically significant by obtaining funding through the INNOVA program in all specifications. Also, it is observed that firms with higher sales, greater numbers of workers and exports are more likely to innovate in products and/or services. Finally, those firms that belong to the manufacturing sector and hotels - restaurants are less likely to innovate in products and/or services.

As mentioned before, the variables that characterize the firm's innovative inputs are only available in the second and third waves of the ELE survey. Therefore, Table 3 excludes the observations of the first wave of the survey in the four previously mentioned specifications, and also includes the specification 5 that also controls by the possession of an R\&D department and by the recruitment of R\&D personnel. 


\section{Mardones / Contaduría y Administración 66(3), 2021, 1-19}

http://dx.doi.org/10.22201/fca.24488410e.2021.2683

Table 2

Estimating the impact of programs with data from the three waves of the ELE survey

\begin{tabular}{|c|c|c|c|c|c|c|c|c|c|c|c|c|}
\hline & \multicolumn{2}{|c|}{ Specification 1} & & \multicolumn{3}{|c|}{ Specification 2} & \multicolumn{3}{|c|}{ Specification 3} & \multicolumn{2}{|c|}{ Specification 4} & \\
\hline & Coef. & St. Dev. & & Coef. & St. Dev. & & Coef. & St. Dev. & & Coef. & St. Dev. & \\
\hline PDP Program & 0.225 & 0.496 & & -0.0337 & 0.484 & & -0.0849 & 0.483 & & -0.156 & 0.486 & \\
\hline INNOVA Program & 1.279 & 0.461 & $* *$ & 1.034 & 0.465 & * & 0.998 & 0.462 & ${ }^{*}$ & 1.157 & 0.46 & * \\
\hline FOGAPE Program & 0.519 & 0.552 & & 0.595 & 0.542 & & 0.631 & 0.546 & & 0.555 & 0.57 & \\
\hline FAT Program & -5.472 & 405.5 & & -5.455 & 1162.3 & & -5.389 & 1178.7 & & -5.103 & 1246.6 & \\
\hline Another CORFO program & 0.966 & 0.375 & $*$ & 0.864 & 0.379 & $*$ & 0.86 & 0.38 & $*$ & 0.696 & 0.376 & \\
\hline $\begin{array}{l}\text { Real sales in millions of } \\
\text { Chilean } \$\end{array}$ & & & & $4.8 \mathrm{E}-07$ & $1.7 \mathrm{E}-07$ & ${ }^{* *}$ & $4.5 \mathrm{E}-07$ & $1.7 \mathrm{E}-07$ & ${ }^{*}$ & 5.7E-07 & $1.82 \mathrm{E}-07$ & $* *$ \\
\hline Number of employees & & & & $1.4 \mathrm{E}-05$ & 4.7E-06 & ** & $1.3 \mathrm{E}-05$ & 4.7E-06 & $* *$ & $1.3 \mathrm{E}-05$ & 4.69E-06 & $* *$ \\
\hline$\%$ National private ownership & & & & 0.00783 & 0.00537 & & 0.00817 & 0.00536 & & 0.00992 & 0.00533 & \\
\hline$\%$ Foreign private ownership & & & & 0.00669 & 0.00554 & & 0.00667 & 0.00553 & & 0.0082 & 0.00549 & \\
\hline Natural person & & & & -0.561 & 0.234 & $*$ & -0.523 & 0.244 & $*$ & -0.443 & 0.25 & \\
\hline Limited liability firm & & & & -0.323 & 0.205 & & -0.343 & 0.206 & & -0.342 & 0.209 & \\
\hline $\begin{array}{l}\text { Limited individual liability } \\
\text { firm }\end{array}$ & & & & -0.329 & 0.341 & & -0.335 & 0.343 & & -0.354 & 0.341 & \\
\hline Collective society & & & & -5.033 & 970.9 & & -5.093 & 961.6 & & -5.253 & 1064.6 & \\
\hline Close corporation & & & & -0.0507 & 0.202 & & -0.116 & 0.206 & & -0.129 & 0.207 & \\
\hline Open corporation & & & & -0.289 & 0.252 & & -0.367 & 0.256 & & -0.477 & 0.254 & \\
\hline Make direct exports & & & & 0.389 & 0.113 & $* *$ & 0.348 & 0.115 & $* *$ & 0.237 & 0.12 & ${ }^{*}$ \\
\hline Small firm 1 & & & & & & & -0.0803 & 0.306 & & -0.125 & 0.299 & \\
\hline Small firm 2 & & & & & & & -0.0606 & 0.253 & & -0.0467 & 0.248 & \\
\hline Medium firm & & & & & & & -0.016 & 0.255 & & 0.0212 & 0.249 & \\
\hline Large firm & & & & & & & 0.14 & 0.253 & & 0.192 & 0.248 & \\
\hline Agricultural sector & & & & & & & & & & 0.295 & 0.219 & \\
\hline Manufacturing industry sector & & & & & & & & & & -0.698 & 0.3 & * \\
\hline Electricity-gas-water sector & & & & & & & & & & 0.269 & 0.167 & \\
\hline Construction sector & & & & & & & & & & 0.156 & 0.251 & \\
\hline Commerce sector & & & & & & & & & & -0.368 & 0.196 & \\
\hline Hotels and restaurants sector & & & & & & & & & & -0.312 & 0.159 & * \\
\hline $\begin{array}{l}\text { Transport-communications } \\
\text { sector }\end{array}$ & & & & & & & & & & -0.0654 & 0.188 & \\
\hline Financial sector & & & & & & & & & & -0.0498 & 0.172 & \\
\hline $\begin{array}{l}\text { Real Estate - Business Services } \\
\text { sector }\end{array}$ & & & & & & & & & & 0.091 & 0.239 & \\
\hline Constant & -1.201 & 0.0618 & ** & -1.811 & 0.527 & ** & -1.856 & 0.577 & $* *$ & -1.953 & 0.58 & $* *$ \\
\hline $\operatorname{Ln} \sigma_{u}^{2}$ & -1.481 & 0.399 & $* *$ & -2.061 & 0.622 & ** & -2.084 & 0.635 & $* *$ & -2.659 & 1.038 & * \\
\hline $\mathrm{N}^{\circ}$ Observations & 1677 & & & 1647 & & & 1647 & & & 1647 & & \\
\hline
\end{tabular}

Source: Own elaboration. Note: $*$ significative at $5 \%$ and $* *$ significative at $1 \%$ 
The results of the probit regressions with random-effects presented in Table 3 show that the impact of the INNOVA program on the probability of innovating in products and services is very similar for the same four specifications reported in Table 2 (including data for the three waves of the ELE survey). However, the most relevant aspect of this analysis is that by including the variables that are controlled by the innovative characteristics of the firms (which are available only for the last two waves of the ELE survey) it is possible to observe that the positive and statistically significant effect of the INNOVA program disappears. This is explained by the inclusion of the variable that reflects the possesion of an R\&D department. Thus, it can be concluded that what actually increases the probability of innovations in products and/or services is this characteristic of firms and not obtaining funding from the INNOVA program. It could even be concluded that as the holding of an R\&D department is an observable characteristic for CORFO when firms make their applications to this program it would be easy to choose as beneficiaries of the program firms that possess this characteristic, which are more likely to innovate even in the absence of the INNOVA program, this is known in the literature as picking winners.

Previous studies that estimated the aggregate impact of public instruments on innovation in Chile using cross-section data conclude that the firms that receive public incentives are more productive and/or innovative (Bravo-Ortega et al., 2014; Alvarez et al., 2011; Benavente, 2005). However, studies that have used panel data to analyze the impact of specific programs (Benavente et al., 2007; Benavente \& Crespi, 2003) or pseudo-panel data to evaluate the aggregate impact of public instruments (Mardones \& Zapata, 2019) do not find effects of public funding on product innovation. The results of these latest studies agree with the findings obtained in the present research, which demonstrates the importance of controlling endogeneity problems and selection bias that can affect the impacts obtained with cross-sectional data. However, a distinctive aspect of this research compared to previous studies is that it evaluates different public instruments and controls for the innovative characteristics at the firm level.

\section{Table 3}

Estimating the impact of programs with data from the last two waves of the ELE survey

\begin{tabular}{cccccccccccc}
\hline & \multicolumn{2}{c}{ Specification 1} & \multicolumn{2}{c}{ Specification 2} & \multicolumn{2}{c}{ Specification 3} & & \multicolumn{2}{c}{ Specification 4} & \multicolumn{2}{c}{ Specification 5} \\
\cline { 2 - 10 } & Coef. & St. Dev. & Coef. & St. Dev. & Coef. & St. Dev. & Coef. & St. Dev. & Coef. St. Dev. \\
\hline PDP Program & 0.0299 & 0.756 & -0.686 & 0.772 & -0.711 & 0.762 & -0.754 & 0.714 & -0.784 & 0.791
\end{tabular}




\section{Mardones / Contaduría y Administración 66(3), 2021, 1-19}

http://dx.doi.org/10.22201/fca.24488410e.2021.2683

\begin{tabular}{|c|c|c|c|c|c|c|c|c|c|c|c|}
\hline INNOVA Program & 1.354 & 0.527 & * $\quad 1.131$ & 0.532 & * 1.076 & 0.526 & * & 1.32 & 0.509 & ** $\quad 0.607$ & 0.528 \\
\hline FOGAPE Program & 0.644 & 0.708 & 0.889 & 0.685 & 0.934 & 0.686 & & 0.688 & 0.678 & 0.206 & 0.695 \\
\hline FAT Program & -7.732 & 1840.2 & -6.533 & 1651 & -6.007 & 736.7 & & -4.979 & 562.8 & -4.046 & 624.8 \\
\hline $\begin{array}{l}\text { Another CORFO } \\
\text { program }\end{array}$ & 1.393 & 0.548 & * $\quad 1.18$ & 0.555 & * 1.149 & 0.553 & $*$ & 0.884 & 0.53 & 0.244 & 0.551 \\
\hline $\begin{array}{l}\text { Real sales in mil- } \\
\text { lions of Chilean \$ }\end{array}$ & & & $1.6 \mathrm{E}-06$ & 3.4E-07 & ${ }^{* *} 1.5 \mathrm{E}-06$ & $3.4 \mathrm{E}-07$ & ** & $1.6 \mathrm{E}-06$ & $3.3 \mathrm{E}-07$ & ${ }^{* *} \quad 1.1 \mathrm{E}-06$ & 3.3E-07 * \\
\hline $\begin{array}{l}\text { Number of em- } \\
\text { ployees }\end{array}$ & & & $1.2 \mathrm{E}-05$ & 5.8E-06 & * $1.1 \mathrm{E}-05$ & 5.7E-06 & & $1.2 \mathrm{E}-05$ & $5.7 \mathrm{E}-06$ & $* \quad 1.4 \mathrm{E}-05$ & $5.7 \mathrm{E}-06$ * \\
\hline $\begin{array}{l}\% \text { National private } \\
\text { ownership }\end{array}$ & & & 0.0036 & 0.00707 & 0.00404 & 0.007 & & 0.00722 & 0.00671 & 0.00908 & 0.00666 \\
\hline $\begin{array}{l}\% \text { Foreign private } \\
\text { ownership }\end{array}$ & & & 0.00057 & 0.00745 & 0.00067 & 0.00736 & & 0.00461 & 0.00704 & 0.0063 & 0.00696 \\
\hline \multirow[t]{2}{*}{ Natural person } & & & & & & & & & & & \\
\hline & & & -0.732 & 0.375 & -0.617 & 0.387 & & -0.665 & 0.383 & -0.599 & 0.363 \\
\hline $\begin{array}{l}\text { Limited liability } \\
\text { firm }\end{array}$ & & & -0.36 & 0.309 & -0.374 & 0.307 & & -0.446 & 0.297 & -0.477 & 0.285 \\
\hline $\begin{array}{l}\text { Limited individual } \\
\text { liability firm }\end{array}$ & & & -0.248 & 0.479 & -0.26 & 0.482 & & -0.318 & 0.461 & -0.381 & 0.466 \\
\hline \multirow[t]{2}{*}{ Collective society } & & & & & & & & & & & \\
\hline & & & -5.364 & 2144.6 & -5.037 & 838 & & -4.776 & 545.8 & -4.582 & 588.1 \\
\hline Close corporation & & & 0.0891 & 0.301 & 0.0185 & 0.303 & & -0.0632 & 0.289 & -0.194 & 0.277 \\
\hline Open corporation & & & -0.372 & 0.377 & -0.434 & 0.376 & & -0.581 & 0.355 & -0.777 & 0.354 * \\
\hline $\begin{array}{l}\text { Make direct } \\
\text { exports }\end{array}$ & & & 0.681 & 0.166 & ** $\quad 0.633$ & 0.168 & ** & 0.417 & 0.168 & * $\quad 0.392$ & $0.168 *$ \\
\hline Small firm 1 & & & & & 0.885 & 0.589 & & 0.978 & 0.599 & 1.027 & 0.668 \\
\hline Small firm 2 & & & & & 0.5 & 0.554 & & 0.672 & 0.565 & 0.853 & 0.637 \\
\hline Medium firm & & & & & 0.644 & 0.551 & & 0.8 & 0.558 & 0.884 & 0.63 \\
\hline Large firm & & & & & 0.806 & 0.546 & & 0.956 & 0.554 & 0.863 & 0.626 \\
\hline Agricultural sector & & & & & & & & 0.729 & 0.295 & * $\quad 0.463$ & 0.288 \\
\hline $\begin{array}{l}\text { Manufacturing } \\
\text { industry sector }\end{array}$ & & & & & & & & -0.966 & 0.49 & * $\quad-0.997$ & 0.453 * \\
\hline $\begin{array}{l}\text { Electricity-gas-wa- } \\
\text { ter sector }\end{array}$ & & & & & & & & 0.441 & 0.233 & 0.148 & 0.233 \\
\hline \multirow[t]{2}{*}{ Construction sector } & & & & & & & & & & & \\
\hline & & & & & & & & 0.127 & 0.338 & 0.0865 & 0.326 \\
\hline Commerce sector & & & & & & & & -0.296 & 0.279 & -0.227 & 0.271 \\
\hline $\begin{array}{l}\text { Hotels and restau- } \\
\text { rants sector }\end{array}$ & & & & & & & & -0.482 & 0.234 & * $\quad-0.489$ & 0.233 * \\
\hline $\begin{array}{l}\text { Transport-commu- } \\
\text { nications sector }\end{array}$ & & & & & & & & -0.374 & 0.297 & -0.536 & 0.298 \\
\hline \multirow[t]{2}{*}{ Financial sector } & & & & & & & & & & & \\
\hline & & & & & & & & 0.0419 & 0.238 & 0.0583 & 0.229 \\
\hline $\begin{array}{l}\text { Real Estate - } \\
\text { Business Services } \\
\text { sector }\end{array}$ & & & & & & & & -0.078 & 0.362 & -0.162 & 0.362 \\
\hline
\end{tabular}




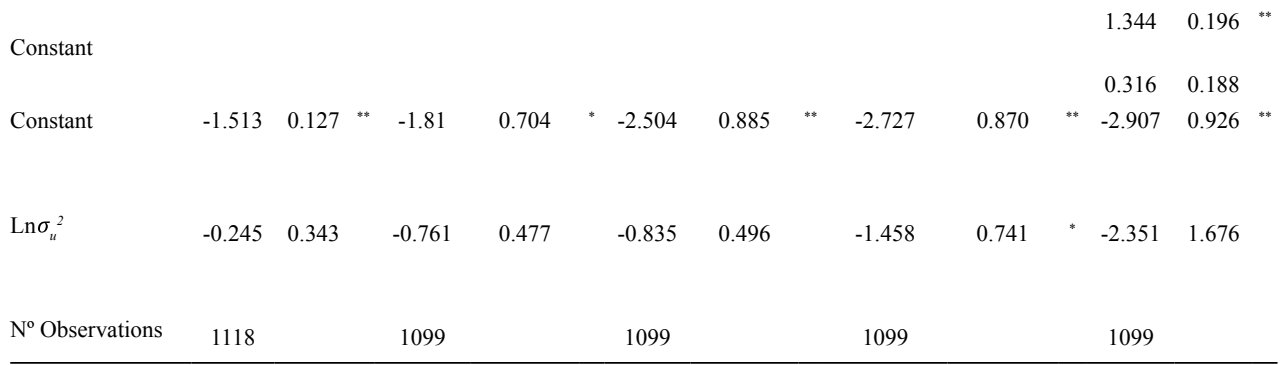

Source: Own elaboration. Note: * significative at $5 \%$ and $* *$ significative at $1 \%$

Additionally, with data from the second and third waves of the ELE survey, it is possible to assess whether CORFO's public funding programs have any impact on the composition of the funding that firms choose to make their investments. Table 4 shows that the INNOVA program does not have a significant effect on the percentage of funding with own funds, factoring or leasing, bank loans, non-bank loans and capital increase, which shows that there is no crowding-out effect from this program on how to finance new investments. However, the FOGAPE program, which is a State guarantee for loans from banks, generates two opposing effects, reduces the need for factoring or leasing significantly, and increases the use of nonbank loans. In addition, the other programs included in the analysis do not have a significant effect on the funding structure of firms.

Table 4

Estimating the impact of programs on the funding structure

\begin{tabular}{|c|c|c|c|c|c|c|c|c|c|c|c|c|}
\hline \multirow[t]{2}{*}{ Funding Source } & \multicolumn{2}{|c|}{ Firm Funds } & \multicolumn{2}{|c|}{$\begin{array}{c}\text { Factoring o } \\
\text { leasing }\end{array}$} & \multicolumn{4}{|c|}{ Bank Loan } & \multicolumn{2}{|c|}{ No-bank loan } & \multicolumn{2}{|c|}{$\begin{array}{r}\text { Capital } \\
\text { increase }\end{array}$} \\
\hline & Coef. & St. Dev. & Coef. & St. Dev. & & Coef. & St. Dev. & & Coef. & St. Dev. & Coef. & St. Dev. \\
\hline PDP Program & 13.66 & 24.50 & 8.10 & 23.70 & & -1.00 & 6.10 & & 0.26 & 5.91 & -4.26 & 10.03 \\
\hline INNOVA Program & -2.14 & 23.01 & 2.86 & 22.26 & & -1.94 & 5.73 & & -2.59 & 5.55 & 0.48 & 9.42 \\
\hline PAE Program & -67.20 & 59.73 & 63.92 & 57.78 & & -2.62 & 14.88 & & -1.60 & 14.40 & 2.91 & 24.46 \\
\hline FOGAPE Program & 7.04 & 30.38 & -60.96 & 29.39 & * & 10.87 & 7.57 & & 32.56 & 7.32 & ** 1.16 & 12.44 \\
\hline FAT Program & 50.00 & 58.75 & -70.00 & 56.83 & & 0.00 & 14.64 & & 0.00 & 14.16 & 0.00 & 24.06 \\
\hline Another CORFO program & -18.38 & 20.66 & 2.64 & 19.99 & & 1.33 & 5.15 & & -1.25 & 4.98 & 12.89 & 8.46 \\
\hline Small firm 1 & -53.94 & 30.91 & 18.25 & 29.90 & & -0.97 & 7.70 & & 2.23 & 7.45 & 34.78 & 12.66 \\
\hline Small firm 2 & -40.95 & 28.39 & 33.13 & 27.46 & & -0.24 & 7.07 & & 1.13 & 6.84 & 6.62 & 11.62 \\
\hline Medium firm & -71.69 & 38.84 & 69.59 & 37.57 & & -4.22 & 9.68 & & 3.20 & 9.36 & 22.78 & 15.90 \\
\hline Large firm & -82.02 & 41.97 & 84.90 & 40.60 & * & 2.52 & 10.46 & & 5.38 & 10.12 & 17.63 & 17.19 \\
\hline Agricultural sector & 8.29 & 48.84 & -61.42 & 47.24 & & 41.24 & 12.17 & ${ }^{* *}$ & 3.32 & 11.77 & 12.35 & 20.00 \\
\hline $\begin{array}{l}\text { Manufacturing industry } \\
\text { sector }\end{array}$ & -6.56 & 71.83 & -29.47 & 69.48 & & 42.05 & 17.89 & * & -2.42 & 17.31 & 2.12 & 29.41 \\
\hline
\end{tabular}




\begin{tabular}{|c|c|c|c|c|c|c|c|c|c|c|c|}
\hline Electricity-gas-water sector & -37.29 & 43.33 & -13.57 & 41.91 & 39.38 & 10.79 & $* *$ & 5.43 & 10.44 & 11.55 & 17.74 \\
\hline Construction sector & -10.08 & 62.97 & 14.49 & 60.91 & 42.12 & 15.69 & $* *$ & -0.89 & 15.18 & -18.13 & 25.78 \\
\hline Commerce sector & -8.65 & 44.50 & -15.50 & 43.05 & 47.39 & 11.09 & $* *$ & 0.53 & 10.73 & 2.56 & 18.22 \\
\hline Hotels and restaurants sector & -6.56 & 41.32 & -29.47 & 39.97 & 42.05 & 10.29 & $* *$ & -2.42 & 9.96 & 2.12 & 16.92 \\
\hline $\begin{array}{l}\text { Transport-communications } \\
\text { sector }\end{array}$ & -2.65 & 47.24 & -9.77 & 45.70 & 20.36 & 11.77 & & -1.65 & 11.39 & -2.57 & 19.34 \\
\hline Financial sector & 8.17 & 55.73 & 9.79 & 53.91 & 43.59 & 13.88 & $* *$ & -0.13 & 13.43 & -43.98 & 22.82 \\
\hline $\begin{array}{l}\text { Real Estate - Business Servi- } \\
\text { ces sector }\end{array}$ & 1.32 & 37.69 & -45.12 & 36.46 & 39.82 & 9.39 & ${ }^{* *}$ & 0.83 & 9.09 & 1.29 & 15.43 \\
\hline$\%$ National private ownership & -0.20 & 0.72 & 0.09 & 0.70 & -0.11 & 0.18 & & -0.04 & 0.17 & 0.16 & 0.30 \\
\hline$\%$ Foreign private ownership & -0.06 & 0.75 & -0.06 & 0.73 & -0.11 & 0.19 & & -0.03 & 0.18 & 0.26 & 0.31 \\
\hline Natural person & . & . & . & . & . & . & & . & . & . & . \\
\hline Limited liability firm & 8.04 & 23.81 & -9.68 & 23.04 & 1.36 & 5.93 & & 0.47 & 5.74 & -2.43 & 9.75 \\
\hline Limited liability firm & 6.77 & 30.86 & -19.62 & 29.86 & 2.67 & 7.69 & & 1.36 & 7.44 & 4.83 & 12.64 \\
\hline Collective society & -50.00 & 41.54 & $4 \mathrm{E}-34$ & 40.19 & $-5 \mathrm{E}-35$ & 10.35 & & $1.2 \mathrm{E}-35$ & 10.01 & $\begin{array}{l}-2 \mathrm{E}- \\
34\end{array}$ & 17.01 \\
\hline Close corporation & 0.99 & 24.73 & 4.07 & 23.92 & 3.11 & 6.16 & & 0.34 & 5.96 & -7.87 & 10.13 \\
\hline Open corporation & -25.19 & 28.03 & 6.39 & 27.11 & 3.46 & 6.98 & & -0.14 & 6.76 & 27.50 & 11.48 \\
\hline Make direct exports & -2.81 & 10.76 & 6.08 & 10.41 & 2.62 & 2.68 & & 1.60 & 2.60 & -2.91 & 4.41 \\
\hline Department of $R \& D$ & 10.35 & 9.18 & -11.16 & 8.88 & 0.85 & 2.29 & & -1.91 & 2.21 & -0.01 & 3.76 \\
\hline $\begin{array}{l}\text { Recruitment of R\&D per- } \\
\text { sonnel }\end{array}$ & 7.49 & 8.15 & -4.24 & 7.89 & -1.30 & 2.03 & & 6.32 & 1.97 & ** -6.90 & 3.34 \\
\hline Constant & 156.60 & 84.95 & -31.59 & 82.18 & -25.64 & 21.16 & & -0.57 & 20.48 & -24.04 & 34.78 \\
\hline $\mathrm{N}^{\circ}$ Observations & 800 & & 800 & & 800 & & & 800 & & 800 & \\
\hline
\end{tabular}

Source: Own elaboration. Note: $*$ significative at $5 \%$ and $* *$ significative at $1 \%$

\section{Conclusions}

Previous studies have found that participating in CORFO funding programs generates positive impacts on sales, profits, labor productivity, total factor productivity, and number of hired workers. However, the present study complements these results by investigating the effect of funding programs on innovation in products and/or services, as one of the evaluated programs known as INNOVA that aims to promote innovation.

To carry out an ex-post evaluation of the most commonly used CORFO-funded programs, information was obtained from the ELE survey, which includes three follow-up waves for the same firms. However, it is only in the last two waves that variables are available that allow controlling for the innovative characteristics of firms such as the recruitment of $R \& D$ personnel and the holding of an R\&D department.

When using the data from the three waves of the LES survey, there is a positive and significant effect of the INNOVA program on the probability of innovating in products and/or services. However, the rest of the programs do not have an impact on the innovative activity of firms. Nevertheless, when the probability of innovating in products and/or services 
is conditioned by the possession of an R\&D department, the statistically significant effect of participating in the INNOVA program disappears. Therefore, it can be concluded that the INNOVA program is not fulfilling its objective of promoting innovation. In addition, since the holding of an R\&D department is an observable characteristic before allocating the funds from the INNOVA program, it is possible to choose as beneficiaries firms that have generated innovation in products and/or services, even without having obtained this public funding, and therefore, the apparent positive effect of the program when it is not controlled by the innovative characteristics would be explained only by the bias in the selection of the beneficiaries.

Additionally, it is determined that the INNOVA program does not generate a substitution effect over other funding sources in the beneficiary firms, but the FOGAPE program helps reduce the need for funding through factoring or leasing, and also increases the use of nonbank loans.

As limitation of this study, it can be mentioned that the available panel data only have three time periods, and in the model specifications that control for innovative characteristics, only two time periods are used. Therefore, it is not possible to carry out placebo tests to simulate effects in periods prior to treatment. However, different model specifications are included to check the robustness of the impacts obtained.

\section{References}

Aiello, F., Albanese, G. and P. Piselli, (2019). Good value for public money? The case of R\&D policy. Journal of Policy Modeling 41(6), 1057-1076. https://doi.org/10.1016/j.jpolmod.2019.02.006

Álvarez, R., Bravo-Ortega, C. and L. Navarro (2011). Innovation, R\&D Investment and Productivity in Chile. Cepal Review 104, 135-160. https://doi.org/10.18356/7ce1ee2d-en

Álvarez R., Crespi G. and C. Conrado (2012). Public programs, innovation, and firm performance in Chile. Inter-American Development Bank, $\mathrm{N}^{\mathrm{o}}$ IDB-TN-375, 1-43. Available at: https://publications.iadb. org/publications/english/document/Public-Programs-Innovation-and-Firm-Performance-in-Chile.pdf Retrieved: 4/12/2021.

Arráiz I., Henríquez F. and R. Stucchi (2012). Supplier development programs and firm performance: evidence from Chile. Small Business of Economics 41, 277-293. https://doi.org/10.1007/s11187-012-9428-x

Baltagi B. (2005). Econometric Analysis of Panel Data. (Third Edition). John Wiley \& Sons, Ltd.

Becker, B. (2015). Public R\&D policies and private R\&D investment: A survey of the empirical evidence. Journal of Economic Surveys 29(5), 917-942. https://doi.org/10.1111/joes.12074

Benavente J. M. and G. Crespi (2003). The Impact of an Associative Strategy (the PROFO Program) on Small and Medium Enterprises in Chile. University of Sussex, SPRU Electronic Working Paper Series No. 88, 1-29. Available at: http://www.sussex.ac.uk/Units/spru/publications/imprint/sewps/sewp88/sewp88.pdf Retrieved: 4/12/2021. 
Benavente J. M. (2004). Innovación tecnológica en Chile: Dónde estamos y qué se puede hacer. Banco Central de Chile. Documentos de Trabajo No 295, 1-32. Available at: https://www.bcentral.cl/ detalle-noticias-y-publicaciones/-/asset_publisher/Exzd719NC3Y6/content/innovacion-tecnologica-en-chile-donde-estamos-y-que-se-puede-hacer-4 Retrieved: 4/12/2021.

Benavente J. M. (2005). Investigación y desarrollo, innovación y productividad: un análisis econométrico a nivel de la firma. Estudios de Economía 32, 39-67. Disponible en https://econ.uchile.cl/uploads/publicacion/04f368169782-4df0-8bf4-573b63ec910c.pdf Retrieved: 4/12/2021

Benavente J. M., Crespi G. and A. Maffioli (2007). Public Support to Firm-Level Innovation: An Evaluation of the FONTEC Program. Working Paper Series OVE/WP/05/07, Inter-American Development Bank. Available at: http://ctie.economia.cl/wp-content/uploads/2017/08/Public-Support-to-Firm-Level-Innovation-FONTEC-2007.pdf Retrieved: 4/12/2021.

Bianchini, S., Llerena, P. and R. Martino (2019). The impact of R\&D subsidies under different institutional frameworks. Structural Change and Economic Dynamics 50, 65-78. https://doi.org/10.1016/j.strueco.2019.04.002

Borrás, S. and J. Edler (2020). The roles of the state in the governance of socio-technical systems' transformation. Research Policy 49(5), 103971. https://doi.org/10.1016/j.respol.2020.103971

Bravo-Ortega, C., J. Benavente and. A. González (2014). Innovation, Exports, and Productivity: Learning and Self-Selection in Chile. Emerging Markets Finance and Trade 50, 68-95. https://doi.org/10.2753/ree1540496x5001s105

Bronzini, R. and P. Piselli (2016). The impact of R\&D subsidies on firm innovation. Research Policy 45(2), 442-457. https://doi.org/10.1016/j.respol.2015.10.008

Castellacci, F. and C. Lie (2015). Do the effects of R\&D tax credits vary across industries? A meta-regression analysis. Research Policy 44(4), 819-832. https://doi.org/10.1016/j.strueco.2019.04.002

Centro Latinoamericano para Desarrollo Rural, RIMISP (2011). Informe final Programas de fomento de CORFO. Ministerio de Economía. Available at: https://www.corfo.cl/sites/Satellite?blobcol=urldata\&blobkey=id\&blobtable=MungoBlobs\&blobwhere $=1475166143291 \&$ ssbinary=true Retrieved: 4/12/2021.

Crespi G., Maffioli A. and M. Melendez (2011). Public Support to Innovation: the Colombian COLCIENCIAS' Experience. Inter-American Development Bank $\mathrm{N}^{\circ}$ IDB-TN-264, 1-22. Available at: https://publications.iadb. org/publications/english/document/Public-Support-to-Innovation-The-Colombian-COLCIENCIAS-Experience.pdf Retrieved: 4/12/2021.

Crespi, G. and P. Zuñiga (2012). Innovation and Productivity: Evidence from Six Latin American Countries. World Development 40(2), 273-290. https://doi.org/10.1016/j.worlddev.2011.07.010

Crespi, G., Giuliodori, D., Giuliodori, R. and A. Rodriguez (2016). The Effectiveness of Tax Incentives for R\&D+i in Developing Countries: The case of Argentina. Research Policy, 45(10), 2023-2035. https://doi.org/10.1016/j. respol.2016.07.006

Crespi, G., Figal Garone, L., Maffioli, A. and E. Stein (2020). Public support to R\&D, productivity, and spillover effects: Firm-level evidence from Chile. World Development, 130, 104948. https://doi.org/10.1016/j.worlddev.2020.104948

d'Artis, K. and B. Siliverstovs (2016). R\&D and non-linear productivity growth. Research Policy 45(3), 634-646. https://doi.org/10.1016/j.respol.2015.12.001

DIPRES (1998). Informe final de evaluación Programa de Asistencia Técnica (FAT). Corporación de Fomento CORFO, Ministerio de Economía, Fomento y Reconstrucción. Available at: http://www.dipres.gob.c1/597/ articles-139667_informe_final.pdf Retrieved: 4/12/2021.

DIPRES (2003). Evaluación de impacto proyectos asociativos de fomento (PROFOs). Corporación de Fomento (CORFO), Ministerio de Economía. Available at: http://www.dipres.cl/597/articles-140995_r_ejecutivo_institucional.pdf Retrieved: 4/12/2021.

DIPRES (2011). Informe final de evaluación de impacto programas de Fomento (CORFO), Ministerio de Economía, Fomento y Turismo. Available at: http://www.dipres.gob.cl/597/articles-163128_informe_final.pdf Retrieved: $4 / 12 / 2021$. 


\section{Mardones / Contaduría y Administración 66(3), 2021, 1-19}

http://dx.doi.org/10.22201/fca.24488410e.2021.2683

Edler, J. and J. Fagerberg (2017). Innovation policy: what, why, and how. Oxford Review of Economic Policy 33(1), 2-23. https://doi.org/10.1093/oxrep/grx001

Fagerberg, J. (2017). Innovation policy: rationales, lessons and challenges. Journal of Economic Surveys, 31(2), 497-512. https://doi.org/10.1111/joes.12164

Fagerberg, J. (2006). Innovation. A guide to the literature. J. Fagerberg, D.C. Mowery, R.R. Nelson (Eds.), The Oxford Handbook of Innovation, Oxford University Press, Oxford, 1-26. https://doi.org/10.4337/9781788110266.00007

Guan J. and R. Yam (2015). Effects of government financial incentives on firms' innovation performance in China: Evidences from Beijing in the 1990s. Research Policy 44, 273-282. https://doi.org/10.1016/j.respol.2014.09.001

Hall B. and A. Maffioli (2008). Evaluating the impact of technology development funds in emerging economies: Evidence from Latin America. The European Journal of Development Research 20(2), 172-198. https://doi. org $/ 10.1080 / 09578810802060819$

Kim, K. (2020). Output additionality of R\&D subsidy on manufacturing venture firms in Korea: The moderating role of subcontracting regime. European Journal of Innovation Management, forthcoming. https://doi.org/10.1108/ EJIM-05-2019-0130

King M. and E. Woolley (2014). Estimating the effect of UK direct public support for innovation. Bis Analysis paper number 04. Department for Business Innovation \& Skills, 1-25. Available at: https://assets.publishing.service. gov.uk/government/uploads/system/uploads/attachment_data/file/369650/bis-14-1168-estimating-the-effect-ofuk-direct-public-support-for-innovation-bis-analysis-paper-number-04.pdf Retrieved: 4/12/2021.

Lee C. (2011). Trade, productivity, and innovation: Firm-level evidence from Malaysian manufacturing. Journal of Asian Economics 22, 284-294. https://doi.org/10.1016/j.asieco.2011.05.003

Liu, X., Li, X. and H. Li (2016). R\&D subsidies and business R\&D: Evidence from high-tech manufacturing firms in Jiangsu. China Economy Review 41, 1-22. https://doi.org/10.1016/j.chieco.2016.08.003

López A. (2009). Las evaluaciones de programas públicos de apoyo al fomento y desarrollo de la tecnología y la innovación en el sector productivo en América Latina. Banco Interamericano de Desarrollo. Nota técnica, 1-47. Available at: https://publications.iadb.org/publications/spanish/document/Las\%20Evaluaciones\%20 de $\% 20$ programas $\% 20$ publicos $\% 20$ de $\% 20$ apoyo $\% 20$ al $\% 20$ fomento $\% 20$ y $\% 20$ desarrollo $\% 20 \mathrm{de} \% 201 \mathrm{a} \% 20$ tecnologia\%20y\%20la\%20innovacion\%20en\%20el\%20sector\%20productivo\%20en\%20America\%20Latina.pdf Retrieved: 4/12/2021

Mardones, C. and A. Zapata (2019). Impact of public support on the innovation probability in Chilean firms. Economics of Innovation and New Technology 28(6), 569-589. https://doi.org/10.1080/10438599.2018.1546548

Marino, M., Lhuillery, S., Parrotta, P. and D. Sala (2016). Additionality or crowding-out? An overall evaluation of public R\&D subsidy on private R\&D expenditure. Research Policy 45(9), 1715-1730. https://doi.org/10.1016/j. respol.2016.04.009

Martin, S. and J. Scott (2000). The nature of innovation market failure and the design of public support for private innovation. Research Policy 29, 437-447. https://doi.org/10.1016/s0048-7333(99)00084-0

Minford, L. and D. Meenagh (2019). Testing a model of UK growth: A role for R\&D subsidies. Economic Modelling 82, 152-167. https://doi.org/10.1016/j.econmod.2019.01.002

Oh, D.S., Phillips, F., Park, S. and E. Lee (2016). Innovation ecosystems: A critical examination. Technovation 54, 1-6. https://doi.org/10.1016/j.technovation.2016.02.004

Petrin, T. (2018). A literature review on the impact and effectiveness of government support for R\&D and innovation. ISI Growth, Working paper 05/2018. Available at: http://www.isigrowth.eu/wp-content/uploads/2018/02/ working_paper_2018_05.pdf Retrieved: 4/12/2021.

Tan, H. (2009). Evaluating SME Support Programs in Chile Using Panel Firm Data. Policy Research. The World Bank Working papers $\mathrm{N}^{\circ}$ 5082. 1, 1-41. Available at: https://openknowledge.worldbank.org/bitstream/handle/10986/4274/WPS5082.pdf?sequence=1\&isAllowed=y Retrieved: 4/12/2021.

Yu, F., Guo, Y., Le-Nguyen, K., Barnes, S. and W. Zhang (2016). The impact of government subsidies and enterprises' R\&D investment: A panel data study from renewable energy in China. Energy Policy 89, 106-113. https:// doi.org/10.1016/j.enpol.2015.11.009 